\title{
The betrayal of Steve Biko - South Africa's Initial Report to the UN Committee against Torture and responses from civil society
}

\author{
LUKAS MUINTINGH ${ }^{1}$ \\ Project Co-ordinator, Civil Society Prison Reform Initiative, Community Law \\ Centre University of the Western Cape
}

\begin{abstract}
"It took the death of Steve Biko under torture to provoke the [UN] General Assembly into drafting and accepting the 1984 Convention against Torture and Other Cruel, Inhuman and Degrading Treatment or Punishment, which requires state parties to take jurisdiction to punish torture committed within their territory either by or against their nationals."
\end{abstract}

\section{INTRODUCTION}

As the above quote demonstrates, South Africa has a special relationship with the UN Convention against Torture and Other Cruel, Inhuman or Degrading Treatment or Punishment (CAT) and ratified it on 10 December 1998. This signified to the international community that South Africa subscribes to the international ban on torture and that it would implement national measures to give effect to the objectives of the Convention. The international ban on the use of torture also has the enhanced status of a peremptory norm of general international law, ${ }^{3}$ meaning that it

"enjoys a higher rank in the international hierarchy than treaty law and even 'ordinary' customary rules. The most conspicuous consequence of this higher rank is that the principle at issue cannot be derogated from by States through international treaties or local or special customs or even general customary rules not endowed with the same normative force." 4

1 The Civil Society Prison Reform Initiative is a project of the Community Law Centre at the University of the Western Cape. The author wishes to acknowledge the support of the Ford Foundation for the work of the Community Law Centre.

2 Robertson G Crimes against Humanity - the struggle for global justice, Penguin, London, (2006) 265.

3 See the recent House of Lords decision in A (FC) and others (FC) v. Secretary of State for the Home Department (2004); A and others (FC) and others v. Secretary of State for the Home Department [2005] UKHL 71 at para 33. See also R v. Bow Street Metropolitan Stipendiary Magistrate, Ex p Pinochet Ugarte (No 3) [2000] 1 AC 147, 197-199; Prosecutor v. Furundzija ICTY (Trial Chamber) judgment of 10 December 1998 at paras 147-157 cited in Fernandez L and Muntingh L (forthcoming) The Criminalisation of Torture in South Africa, CSPRI Research Report.

4 Prosecutor v. Furundzija ICTY (Trial Chamber) Judgment of 10 December 1998 at para 153 (Case no. IT/95-17/1/T) cited in Fernandez L and Muntingh L (fn 3 above). 
The prohibition on torture imposes obligations on states owed to other members of the international community, each of which then has a correlative right. ${ }^{5}$ It signals to all states and people in their respective jurisdictions that "the prohibition of torture is an absolute value from which nobody must deviate." At national level, it de-legitimates any law or administrative or judicial act authorising torture. ${ }^{7}$ Also, no state may excuse itself from the application of the peremptory norm. The revulsion with which the torturer is regarded is demonstrated by the very strong judicial rebuke, condemning the torturer as someone who has become "like the pirate and slave trader before him - hostis humani generis, an enemy of all mankind", ${ }_{8}$ and torture itself as an act of barbarity which "no civilized society condones," "one of the most evil practices known to man"10 and "an unqualified evil". ${ }^{11}$

There is little doubt that torture is still taking place in South Africa, especially where people are deprived of their liberty. This has been established by several researchers and oversight structures. ${ }^{12}$ The 2006/7 Department of Correctional Services Annual Report reflects that 62 prisoners died in that year due to unnatural causes. ${ }^{13}$ Moreover, the Judicial Inspectorate of Prisons recorded a total of 2494 complaints from prisoners in 2005/6 alleging that they had been assaulted by prison warders. ${ }^{14}$ The 2004/5 Independent Complaints Directorate (ICD) Annual Report similarly reflects on a number of cases where torture and assault of police suspects are alleged. ${ }^{15}$ The 2005/6 Annual Report of the ICD provides more detail: of 1787 cases against police officers investigated by the ICD, $62 \%$ related to assault, attempted murder,

5 Prosecutor v. Furundzija para 151 (fn 3 above). The violation of such an obligation constitutes a "breach of the correlative right of all members of the international community and gives rise to a claim for compliance accruing to each and every member, which then has the right to insist on fulfillment of the obligation or in any case to call for the breach to be discontinued".

6 Prosecutor $v$. Furundzija (fn 3 above) para 154

7 Prosecutor v. Furundzija (fn 3 above) para 155.

8 Filartiga v. Pena-Irala [1980] 630 F (2nd Series) 876 US Court of Appeals 2nd Circuit 890, cited in Fernandez L and Muntingh L (forthcoming) (fn 3 above).

9 A (FC) and others v. Secretary of State for the Home Department para 67, cited in Fernandez L and Muntingh L (forthcoming) Note 3.

10 Filartiga $v$. Pena-Irala (fn 9 above) para 101

11 Filartiga v. Pena-Irala (fn 9 above) para 160. See also Fernandez and Muntingh (forthcoming) (fn 3 above).

12 See Bruce D, Newham and Masuku T (2007) In Service of the People's Democracy - an assessment of the South African Police Service, CSVR, Johannesburg. Also Muntingh L and Fernandez L (forthcoming) (fn 3 above).

13 Department of Correctional Services Annual Report 2006/7, (2007) Pretoria 38.

14 Office of the Inspecting Judge Annual Report of the Judicial Inspectorate 2005/6, Cape Town, (2006) 11. The 2006/7 annual report of the Office of the Inspecting Judge does not provide information on the number of complaints recorded and their breakdown.

15 See for example the following cases from the ICD Annual Report 2004/5 listed according to the relevant police station: Moroka (p. 59), Zonkisizwe (p. 59), Linden (p. 60), Smithfield (p. 61), Odendaalsrus (p. 61), Klerksdorp (p. 63), and Benoni (p. 66). The ICD Annual Report 2005/6 present similar cases involving assault and torture listed according to the relevant police station: Wolmaransstad (p. 52), Ipelegeng (p. 52), Queenstown (p. 52), Mthatha (p. 52). 
intimidation and torture. ${ }^{16}$ The assault and torture of people in police custody and in prisons therefore appears to be common and often lead to fatalities.

This article will focus on State Party obligations in respect of reporting to the UN Committee against Torture (the Committee) under article $19(1)^{17}$ of CAT and more particularly on civil society's interaction with the Committee in respect of South Africa's Initial Report. ${ }^{18}$ It will be argued that the provisions of CAT, the Rules of Procedure of the Committee, ${ }^{19}$ and the Working Methods of the Committee ${ }^{20}$ are in fact facilitative and supportive of civil society participation in the work of the Committee. Using the submissions made by six civil society organisations during the Committee's consideration of South Africa's Initial Report, ${ }^{21}$ evidence is provided that the majority of the issues raised by civil society organisations found their way into the Committee's Concluding Remarks $^{22}$ in respect of the Initial Report. This is regarded as a positive step towards greater transparency and accountability in respect of the protection of the right to freedom from torture in a global human rights framework.

Government support for the prevention and combating of torture remains less than enthusiastic thirty years after Steve Biko was tortured to death in detention by apartheid-era police. The lack of progress and political support for preventing and combating torture is even more perplexing when reading President Thabo Mbeki's Steve Biko Memorial Lecture delivered in 2007 in which he poignantly cites the attributed words of Biko to his torturers:

"I ask for water to wash myself with and also soap, a washing cloth and a comb. I want to be allowed to buy food. I live on bread only here. Is it compulsory for me to be naked? I am naked since I came here."23

16 Independent Complaints Directorate Annual Report 2006/7, Pretoria, (2007) at p. 63-64. The following specific offence categories are being referred to: assault common, assault with the intention of causing grievous bodily harm, attempted murder, beaten with handcuffs, beaten with fists, dog attack, emotion/verbal/psychological abuse, indecent assault, intimidation, kicked, kidnapping, physical abuse, pointing of firearm, rape and torture.

17 United Nations Convention against Torture and Other Cruel Inhuman or Degrading Treatment or Punishment article 19(1) states as follows:

"The States Parties shall submit to the Committee, through the Secretary-General of the United Nations, reports on the measures they have taken to give effect to their undertakings under this Convention, within one year after the entry into force of the Convention for the State Party concerned. Thereafter the States Parties shall submit supplementary reports every four years on any new measures taken and such other reports as the Committee may request."

18 Republic of South Africa (2002) Initial Report to the Committee against Torture, CAT/C/52/Add.3, 25 August 2005.

19 Committee Against Torture (2002) Rules of Procedure, CAT/C/3/Rev.4, 9 August 2002 http://www.unhchr. ch/tbs/doc.nsf/898586b1dc7b4043c1256a450044f331/1447cc84665815d5c1256c4700309a65/ \$FILE/G0244257.pdf

20 Committee against Torture, Working Methods http://www.ohchr.org/english/bodies/cat/workingmethods.htm

21 37th Session of the Committee against Torture, Geneva, November 2006.

22 UN Committee against Torture (2006) Consideration of Reports Submitted By States Parties Under Article 19 of the Convention Conclusions and recommendations of the Committee against Torture - South Africa CAT/C/ZAF/CO/1, 37th session, 6-24 November 2006.

23 Steve Biko Memorial Lecture delivered by the President of South Africa, Thabo Mbeki, on the occasion of the 30th Anniversary of the death of Stephen Bantu Biko, Cape Town, 12 September 2007, http://www.info.gov.za/speeches/2007/07091314151001.htm accessed on 25 September 2005. 
Nine years after South Africa ratified CAT, torture has not specifically been criminalised in domestic law - although criminal law, of course, prohibits assault and murder by state officials. State officials remain largely unaware of the international ban on the use of torture. ${ }^{24}$ Legislation regulating places of detention is devoid of the language of CAT. It is in this sense that one can talk of a betrayal by not honouring the memories of those who suffered at the hands of perpetrators of torture and being complacent when allegations of torture are made.

\section{REPORTING REQUIREMENTS}

Since this was South Africa's first engagement with the Committee against Torture, it is necessary to explain the procedure contained in CAT that is applicable during such an engagement. Under article 19(1) State Parties are obliged to submit an Initial Report within twelve months after ratification of CAT. After submitting this Initial Report State Parties have a duty to report every four years to the Committee on progress made towards implementing measures to give effect to the Convention. ${ }^{25}$ The UN Secretary-General is also mandated to distribute these reports to all states party to CAT. ${ }^{26}$ In order to avoid the lengthy repetition of historical and general statutory and policy provisions in the Initial and Periodic Reports, general reporting guidelines in respect of the International Human Rights Instruments require that State Parties submit a "common core document" that provides an overall description of human rights in the territories of the respective state and, secondly, the submission of treaty specific reports. ${ }^{27}$ This split reporting is evidently a measure aimed at improving efficiency and at preventing State Parties from repeating general information in respect of human rights issues in that state for each treaty-specific report. With regard to Initial Reports submitted under article 19(1) of CAT, the Committee has issued "Guidelines on the form and content of Initial Reports under article 19 to be submitted by states parties to the Convention against Torture" ("the Guidelines"); and these Guidelines note at the outset that the Initial Report should cross-refer to the "common core document" and not repeat what is already stated there. ${ }^{28}$

Given the fact that the common core document is supposed to describe the overall historical, constitutional, statutory and policy framework of the State Party, the idea is that the Initial Report will then aim at providing the Committee with recent information on measures taken by the State Party to give effect

24 SAPS is the only government department that has a policy on the prevention of torture.

25 CAT (fn 17 above) article 19(1).

26 CAT (fn 17 above) article $19(2)$ reads as follows:

"The Secretary-General of the United Nations shall transmit the reports to all States Parties."

27 UN International Human Rights Instruments (2004) Guidelines on an expanded core document and treaty-specific targeted reports and harmonized guidelines on reporting under the international human rights treaties, HRI/MC/2004/3, 9 June 2004 http://daccessdds.un.org/doc/UNDOC/GEN/ G04/421/61/PDF/G0442161.pdf?OpenElement

28 UN Committee against Torture (2005) Guidelines on the form and content of initial reports under Article 19 to be submitted by states parties to the Convention against Torture, CAT/C/4/Rev.3, 18 July 2005, par 3 . 
to its undertakings under CAT. ${ }^{29}$ The Guidelines direct the State Party towards providing evidence of measures taken to give effect to the Convention, as opposed to describing the overall legislative framework and "the Committee envisages receiving specific information related to the implementation of the Convention to the extent that it is not covered by the core document". The Committee therefore expects the report to

"[p]rovide an overview of the practical implementation of the Convention at the federal,
central, regional and local levels of the State, and indicate any factors and difficulties
that may affect the fulfilment of the obligations of the reporting State under the Conven-
tion. The report should include specific information related to the implementation of the
Convention in such circumstances. Relevant documentation collected by the authorities
or other private or public institutions is welcome." ${ }^{30}$ The Guidelines further emphasise the need to report on the actions of the executive, proactive measures put in place (e.g. training programmes), the distribution of functions in the executive and the assessment of the effectiveness of measures taken to implement the provisions of CAT. It is not necessary to describe these in detail here, but it is clear that the Guidelines are aimed at ensuring that the Committee is provided with relevant information that would allow it to make a well-informed evaluation of the current situation with reference to the State Party's obligations under CAT. To facilitate such a report, the Committee recommends that there should be broad-based consultations with stakeholders in the preparation of the report and refers specifically to national institutions promoting and protecting human rights as well as nongovernmental organisations. ${ }^{31}$

Three issues are thus important in respect of reporting: the regularity of reporting, the quality and scope of the report, and the desired inclusive nature of report preparation. It should be borne in mind that the report is not an end itself but forms the basis for dialogue between the Committee and the State Party and may lead to further decisions and actions by the Committee - for example, to request additional information or even visit the State Party if the Committee deems it necessary. ${ }^{32}$

\section{CIVIL SOCIETY PARTICIPATION IN RESPECT OF REPORTS SUBMITTED UNDER ARTICLE 19}

A basic assumption underlying the Convention - an assumption also shared by other treaties such as the Convention on the Rights of the Child - is that States Parties might be reluctant to reveal all the relevant facts in their reports. Consequently, other stakeholders are afforded ways of furnishing the Committee with information to ensure that even facts that may embarrass the State Party will be made available to the Committee. In particular, opportunities are created for civil society organisations to provide the Committee with

29 UN Committee against Torture (2005) (fn 28 above) par 1. This is also the same wording used in Article 19(1) (fn 3 above).

30 UN Committee against Torture (2005) (fn 28 above) par 5.

31 UN Committee against Torture (2005) (fn 28 above) par 4.

32 UN Committee against Torture (2002) (fn19 above) Rules 67 and 80. 
information additional and alternative to the State Party's reports. Article 18(2) of CAT enables the Committee to establish its own Rules of Procedure, and the Committee has crafted these in a manner supportive of civil society participation in its work. Such participation is provided for in CAT itself, the Rules of Procedure, the Reporting Guidelines and the Working Methods of the Committee. A brief description of the relevant features follows with reference to reports submitted under article 19.

The Guidelines encourage civil society's participation in the preparation of an Initial or Periodic Report - submitted in accordance with article $19-$ which should, as alluded to above, emanate from broad-based consultations with stakeholders, especially with civil society and national institutions with a mandate to promote and protect human rights. ${ }^{33}$ The Guidelines request, in particular, information on the process followed to ensure such consultation, presumably for the Committee to assess the scope and depth of such consultations, and also to help it to reflect on the State Party's efforts to prepare the report in a transparent and inclusive manner. The document entitled Working Methods of the Committee also support the involvement of national institutions and non-governmental organisations in the process of consultations that would lead to the preparation of reports by States Parties. ${ }^{34}$

In an effort to streamline and focus its discussions in respect of Periodic Reports, the Committee amended its procedures in 2004 to provide for "a list of issues" to be communicated to the State Party approximately one year in advance of the consideration of the State Party's periodic report. ${ }^{35}$ The intention is that the State Party concerned should distribute the list of issues widely, including to civil society organisations. The list of issues is also made available on the Committee's website and thus accessible to civil society organisations. Civil society organisations may also make submissions to the Committee in respect of issues that it would like to see included in the list of issues communicated to the State Party in preparation of the Periodic Report.

Once a State Party has submitted its Initial or Periodic Report, civil society organisations have the opportunity to submit written information in the form of shadow reports. This is probably the most frequently used and most accessible avenue for civil society participation in the work of the Committee and is provided for under the Committee's Rules of Procedure:

"The Committee may invite specialized agencies, United Nations bodies concerned, regional intergovernmental organizations and non-governmental organizations in consultative status with the Economic and Social Council to submit to it information, documentation and written statements, as appropriate, relevant to the Committee's activities under the Convention." ${ }^{36}$

These reports may provide a comprehensive overview in respect of all articles of CAT or they may elect to focus on one or more particular themes. There

33 UN Committee against Torture (2005) (fn 28 above) par 4.

34 UN Committee against Torture (2005) (fn 28 above) par II.

35 Committee against Torture (fn 20 above) par III (A).

36 UN Committee against Torture (2002) (fn 19 above) Rule 62(1). 
are no prescriptions in this regard. Civil society organisations are also free to compile one coordinated response or to make individual submissions. The document entitled Working Methods of the Committee, through rule 62, invites non-governmental organisations to the activities of the Committee. Non-governmental organisations usually engage with the Committee pursuant to rule 62 by way of written reports, copies of which are provided to the State Party concerned unless the authors object. Representatives of civil society organisations may also brief the Committee orally during the session when the State Party's report is considered, without State Party representatives being present. ${ }^{37}$

In the past, civil society groups have engaged with the Committee on the Initial and Periodic Reports of various State Parties in an informal manner. However, since 2004 such contributions have taken on a formal character, with representatives from civil society now being afforded a confidential session with the Committee on the basis of written submissions made to the Committee in advance of such a session. ${ }^{38}$ This confidential session takes place prior to the Committee's interaction with the government delegation, which is a session open to the public. Although the session with the civil society representatives is scheduled for only 45 minutes, it provides an important opportunity for all the Committee members to interact with these stakeholders in a formal manner. During this session civil society representatives can raise and/or emphasise any particular issues with the Committee, and also answer specific questions from Committee members. This is a useful opportunity for constructive dialogue between the Committee and the civil society representatives. This is a significant improvement because, as was noted above, prior to 2004 the interaction between Committee members and civil society representatives occurred informally outside of the Committee meeting. ${ }^{39}$

During the open session at which the Committee considers the State Party's Report, Committee members may ask questions of the State Party delegation and the State Party then has the opportunity to respond to such questions in writing by the following day. Civil society organisations that are present at this open session may also use the opportunity to respond in writing to these questions and are allowed to submit their responses to the Committee Secretariat within the same stipulated time.

After the Committee has considered a country's report, it may make such concluding remarks and observations as it deems fit. The content of these remarks are deliberated on in closed session but, once approved, are read into the minutes of the meeting and made available on the Committee's website. ${ }^{40}$ The Committee may also request the State Party to respond to certain issues

37 UN Committee against Torture (fn 20 above) Par VIII.

38 UN Committee against Torture (2004) Summary record of the second part (public) of the 619th meeting, 12 August 2004 CAT/C/SR.619/Add.1.

39 Ibid.

40 CAT (fn 17 above) Article 19(2) and UN Committee Against Torture (fn 20 above) par III(C). 
within a stipulated time frame. ${ }^{41}$ The Concluding Remarks are presented in a structured format, dealing firstly with positive aspects, followed by problematic aspects in the State Party's Report. The State Party may then respond to all or a selection of the questions or issues raised by the Committee. The State Party may elect to have its responses made public, which will then be published as an official committee document. ${ }^{42}$ As the Concluding Remarks are made public shortly after the consideration of the State Party's report, this presents a further opportunity for civil society organisations to submit additional information to the Committee. Neither the Committee's Rules of Procedure nor the Working Methods document provide clear guidance on this. The assumption is that there is nothing preventing civil society organisations from submitting such responses to the Committee. The Concluding Remarks furthermore provide an agenda for government and civil society representatives to potentially engage in dialogue on the issues raised by the Committee. Government may indeed use the Concluding Remarks as an opportunity for broad-based consultation in preparing its responses, as it is encouraged to do in respect of the Initial and Periodic Reports.

\section{SOUTH AFRICA'S INITIAL REPORT}

South Africa's Initial Report was submitted in June 2005 although it had been due in January 2000. It was considered in November 2006 at the Committee's $37^{\text {th }}$ Session in Geneva. An overview of the report is presented here and the full report should be consulted for more detail. At the outset the Committee remarked that the report did not fully conform to the Committee's guidelines for the preparation of initial reports, not least because it limited "itself to statutory provisions rather than analysing the implementation of the Convention's provisions". ${ }^{43}$ A large part of the report could in fact have been dealt with in the common core document, as the Guidelines suggest. The report itself is furthermore dated 2002, placing a second limitation on its scope and depth. ${ }^{44}$

Part I of the 88-page report (28 pages in length) deals with the pre- and post apartheid history of South Africa. Part II (8 pages) describes South Africa's political structure, the legal framework within which human rights are addressed, and the available remedies and rehabilitation programmes that exist in South Africa. It focuses mainly on the Bill of Rights, describing the duties and functions of the national institutions for the promotion and protection of human rights. Part III (59 pages) deals with the individual articles of CAT and the South African situation. The report describes a number of legislative and policy reforms undertaken since 1994 to strengthen the protection of human rights. It also refers to the relevant case law. The report refers to problems faced by the government in realising human rights and notes, for

41 UN Committee against Torture (2002) (fn 19 above) Rule 68(2).

42 CAT (fn 19 above) article 19(2) and UN Committee against Torture (fn 20 above par) III(C).

43 UN Committee against Torture (2006) (fn 22 above) par 3.

44 Republic of South Africa Republic of South Africa Initial Report to the Committee against Torture (2002) (fn 18 above). 
example, that the government is faced with severe prison overcrowding. It also discusses the work of oversight agencies, such as the ICD and the Judicial Inspectorate of Prisons, as well as the contributions of non-governmental organisations in protecting human rights.

South Africa has to be commended for submitting its Initial Report, albeit late, as well as for the honesty in reporting on some of the sensitive issues, such as the handing over of a terrorism suspect, Mr. Mohammed, to US authorities without seeking assurances that he would not face the death penalty in that country. ${ }^{45}$ The report also lists several cases of complaints lodged with the ICD against police officers for assault and offences that could be construed as torture. ${ }^{46}$

The time period covered by the report (1999 to 2001) and its lateness (by six years) are, however, significant limitations, eroding its relevance and accuracy. The second limitation is its lack of depth. While it describes constitutional, legislative and policy measures adopted in line with CAT, it seldom moves beyond this to provide critical insight into the success or failure of measures taken to give effect to the objectives of CAT. The Guidelines are clear on what the Initial Report should contain in respect of each article:

"Cases or situations of violation of the Convention, the reasons for such violations and the measures taken to remedy the situation. It is important for the Committee to obtain a clear picture not only of the legal situation, but also of the de facto situation." ${ }^{47}$

The Initial Report must have left the Committee with an adequate description of the legal situation but failed to provide sufficient detail to give insight into the practical state of affairs regarding adherence to CAT.

\section{THE SOUTH AFRICAN CIVIL SOCIETY SUBMISSIONS}

Three international non-governmental organisations ${ }^{48}$ as well as three domestic non-governmental organisations submitted reports to the Committee in response to the Initial Report. ${ }^{49}$ Five of the organisations also made oral submissions to the Committee in Geneva in November 2006 during the $37^{\text {th }}$ session of the Committee. ${ }^{50}$

45 Republic of South Africa (2002) Initial Report to the Committee against Torture (fn 18 above) paras 102 - 106. The case of Mr. Mohammed ended up in the Constitutional Court as Mohammed and Another $v$ President of the Republic of South Africa and Others 2001 (3) SA 893 (CC).

46 Republic of South Africa Initial Report to the Committee against Torture (2002) (fn 18 above) paras $152-157$.

47 Committee against Torture (2005) (fn 28 above) para 6.

48 These organisations were Amnesty International (AI), the Global Initiative to End All Corporal Punishment of Children (only written submission), and the World Organisation Against Torture.

49 The three submissions from domestic non-governmental organisations came from the Civil Society Prison Reform Initiative (CSPRI) and the Children's Rights Project (CRP), both projects of the Community Law Centre (University of the Western Cape), and the Centre for the Study of Violence and Reconciliation (CSVR).

50 All the relevant documentation and submissions are available on the Committee website at http:// www.ohchr.org/english/bodies/cat/cats37.htm 
None of the civil society submissions provided a comprehensive shadow report on CAT in response to the Initial Report but rather chose to highlight particular themes and issues. While the Initial Report covered the period 1999 to 2002, the civil society submissions were not limited to this period and provided more current information. In fact, most of the civil society submissions focused on current policy and practice, emphasising issues of concern and implementation challenges in South Africa's measures, or lack thereof, to give effect to the Convention. A general concern was, however, the lateness of the report, as well as the fact that it did not provide an adequate description of the measures undertaken and the problems encountered in giving effect to the Convention. Also worth noting is that the three South African organisations made supplementary submissions in response to questions raised by the Committee, to which the South African government delegation responded the following day. The supplementary submissions are unfortunately not available on the Committee's website.

A number of the issues raised by the civil society organisations in their written submissions will be highlighted below with reference to particular articles of the Convention.

\section{Articles 2 and $4^{51}$}

Article 2 of CAT requires State Parties to take effective legislative, administrative, judicial or other measures to prevent acts of torture in any territory under its jurisdiction, while article 4 requires State Parties to ensure that all acts of torture are criminalised. The submissions by AI, CSPRI and CSVR noted that inadequate legislative measures are in place in South Africa to criminalise torture, and CSPRI commented specifically on the inadequacy of two draft bills aimed at criminalising torture. The organisations also commented critically on the inadequacy of the ICD when investigating police abuses. The submissions noted with grave concern that the definition of torture set out in article 1 of CAT had not been incorporated into South African law, as is required by article 4 of that Convention. For example, CSPRI observed,

" $[\mathrm{t}] \mathrm{o}$ inspire public confidence in the Government's determination to criminalise torture, an enactment that outlaws torture must provide a credible means for the victims of torture to bring the matter to the courts. The present Bill is conspicuously silent on this matter.

51 CAT (fn 19 above) article 2 and 4 states that:

"Article 2

(1) Each State Party shall take effective legislative, administrative, judicial or other measures to prevent acts of torture in any territory under its jurisdiction.

(2) No exceptional circumstances whatsoever, whether a state of war or a threat of war, internal political in stability or any other public emergency, may be invoked as a justification of torture.

(3) An order from a superior officer or a public authority may not be invoked as a justification of torture.

Article 4

(1) Each State Party shall ensure that all acts of torture are offences under its criminal law. The same shall apply to an attempt to commit torture and to an act by any person which constitutes complicity or participation in torture.

(2) Each State Party shall make these offences punishable by appropriate penalties which take into account their grave nature." 
The Country Report, on the other hand, refers to a host of enactments, constitutional bodies, judicial decisions, government initiatives and plans aimed at promoting human rights. No doubt, these are important and welcome advances in a country blighted by the inhumanity of Apartheid, and need to be supported. But we need to realise, too, that successes on this front are limited to the goals they set out to achieve, and even then, their usefulness is limited to those who know about their existence and how to go about obtaining relief. None of the institutions referred to in the Report can be said to be specifically geared to cases of torture, for this is an area that demands a great deal of investigative expertise, from the investigative stage, through the medical examination stage, right up to the prosecution of the crime." 52

\section{Article $3^{53}$}

Article 3 deals with the prohibition on the return of persons to their country of origin where there are substantial grounds for believing that such an individual would be in danger of being subjected to torture. AI's submission raised concerns under article 3 of CAT in respect of the treatment of asylum seekers, illegal immigrants and terrorism suspects. Following from this it raised particular concerns about refoulement and gave a detailed account of events surrounding the handing over of Khalid Rashid to Pakistani authorities on 6 November 2005. Mr Rashid was apparently handed over without following the required procedures and without ascertaining whether he was in danger of being tortured by the Pakistani authorities. AI cited two further cases, one involving Mohammed Hendy and the other Jamil Odys (both Jordanian nationals) who were arrested by the police in April 2004, who suspected them of having links with terrorist organisations, and held incommunicado in police cells in Pretoria. Odys was deported whereas Hendy's lawyers were able to secure his release though a habeas corpus action in the High Court. The submission also noted with concern a statement made by the Commissioner of Police to Parliament in May 2004 that the security services had in April of that year arrested and deported a number of "terrorism suspects". It noted also that the Police Commissioner refused to provide further details of these deportations. ${ }^{54}$

In its submission, the CSVR expressed concern about the long delays experienced by asylum-seekers and pointed out that they often wait as long as four years to have their refugee status determined. It is reportedly during this period that asylum-seekers are extremely vulnerable to police harassment. Using the experience of Zimbabwe nationals as an example, the CSVR

52 Muntingh L and Fernandez L Civil Society Prison Reform Initiative (CSPRI) Submission to the UN Committee Against Torture In Response to "Republic Of South Africa - First Country Report On The Implementation Of The Convention Against Torture, And Other Cruel, Inhuman And Degrading Treatment Of Punishment", CSPRI, Bellville, (2006) par 17.

53 CAT (fn 19 above) article 3 states that

“(1) No State Party shall expel, return ("refouler") or extradite a person to another State where there are substantial grounds for believing that he would be in danger of being subjected to torture.

(2) For the purpose of determining whether there are such grounds, the competent authorities shall take into account all relevant considerations including, where applicable, the existence in the State concerned of a consistent pattern of gross, flagrant or mass violations of human rights."

54 Amnesty International South Africa - briefing for the committee against torture, AFR 53/002/2006, London (2006) 1. 
submitted that torture survivors seeking asylum in South Africa are at real risk of being returned to their country of origin in violation of article 3 of the Convention, as "the rights of torture survivors to be protected and granted asylum are quite restricted in South Africa". ${ }^{55}$

\section{Articles $10^{56}$}

Article 10 requires State Parties to ensure that education and information regarding the prohibition against torture are fully included in the training of law enforcement personnel, civil or military, medical personnel, public officials and other persons who may be involved in the custody, interrogation or treatment of any individual. The lack of public knowledge and, more specifically, the lack of training received by officials in South Africa in respect of CAT and the absolute prohibition of torture were raised as concerns by CSPRI in its submission.

\section{Article $11^{57}$}

Article 11 requires State Parties to systematically review interrogation rules, instructions, methods and practices as well as arrangements for the custody and treatment of persons subjected to any form of arrest, detention or imprisonment in any territory under its jurisdiction in order to ensure the prevention of torture. Whereas the Initial Report dealt with an overview of the legislative and policy framework, the submission by CSPRI referred to two specific cases, one involving the death of a female prisoner (M. Syfers) at Pollsmoor Prison and the other involving an alleged mass assault of prisoners that took place at St Alban's Prison in July 2005. ${ }^{58}$ The two cases demonstrated the problems occurring at ground level and the apparent reluctance of authorities to conduct criminal investigations of alleged acts of torture and abuse. The submission further recommended more active involvement of the Judicial Inspectorate of Prisons in monitoring the investigation of such cases.

55 Motala A, Ernest C, Bruce D and Dissel A Submission by the Centre for the Study of Violence and Reconciliation to the UN Committee against Torture in response to "The Republic of South Africa - first Country report on the Implementation of the Convention against Torture, Cruel, Inhuman of Degrading Treatment or Punishment, Centre for the Study of Violence and Reconciliation, Johannesburg,(2006) 7.

56 CAT (fn 19 above) article 10 states that:

"(1) Each State Party shall ensure that education and information regarding the prohibition against torture are fully included in the training of law enforcement personnel, civil or military, medical personnel, public officials and other persons who may be involved in the custody, interrogation or treatment of any individual subjected to any form of arrest, detention or imprisonment.

(2) Each State Party shall include this prohibition in the rules or instructions issued in regard to the duties and functions of any such person."

57 CAT (fn 19 above) article 11 states that:

"Each State Party shall keep under systematic review interrogation rules, instructions, methods and practices as well as arrangements for the custody and treatment of persons subjected to any form of arrest, detention or imprisonment in any territory under its jurisdiction, with a view to preventing any cases of torture."

58 Muntingh and Fernandez (2006) (fn 52 above) 19-20. 


\section{Article $12^{59}$}

Article 12 requires State Parties to ensure that the competent authority promptly and impartially launches an investigation when there is reasonable ground to believe that an act of torture has been committed in any territory under its jurisdiction. Given this requirement, the submissions by AI, CSPRI and CSVR raised concerns about the adequacy of investigations into alleged abuses by officials of the South African Police Service (SAPS) and the Department of Correctional Services (DCS). AI also highlighted the remarks made by the Commissioner of Police in May 2006 questioning the usefulness of the ICD in providing oversight over the SAPS. These submissions provided detailed descriptions of problems encountered in this regard and cited cases where investigations have failed. Both the CSPRI and AI submissions raised concerns about the independence, impartiality and effectiveness of the ICD, while the AI submission referred to a "systematic failure to investigate and bring to justice perpetrators of torture". ${ }^{60}$

\section{Article $13^{61}$}

Article 13 of CAT guarantees the right of any individual who alleges he or she has been subjected to torture to complain to, and to have his or her case promptly and impartially examined by, the competent authorities, and places a duty on State Parties to take steps to ensure that the complainant and witnesses are protected against all ill-treatment or intimidation as a consequence of such complaint. The CSPRI submission emphasised the problems in the prison system in South Africa with regard to investigations and highlighted the secondary victimisation of alleged victims of torture, as well as the undermining of investigations by corrupt and complicit officials. The present practice that members of the SAPS investigate complaints laid by prisoners against prison officials in assault cases, for example, was regarded as a serious flaw in the investigative regime.

59 CAT (fn 19 above) article 12 states that:

"Each State Party shall ensure that its competent authorities proceed to a prompt and impartial investigation, wherever there is reasonable ground to believe that an act of torture has been committed in any territory under its jurisdiction."

60 Amnesty International (2006) (fn 54 above) 7.

61 CAT (fn 19 above) article 13 states that:

"Each State Party shall ensure that any individual who alleges he has been subjected to torture in any territory under its jurisdiction has the right to complain to, and to have his case promptly and impartially examined by, its competent authorities. Steps shall be taken to ensure that the complainant and witnesses are protected against all ill-treatment or intimidation as a consequence of his complaint or any evidence given." 


\section{Article $14^{62}$}

Article 63 of CAT places a duty on State Parties to ensure that victims of torture are afforded redress in its legal system and that it provides for an enforceable right to fair and adequate compensation, including the means for as full rehabilitation as possible, and extends this right to the dependants of a torture victim who was killed. In its submission, CSVR highlighted the absence of prosecutions of crimes committed under apartheid and drew the Committee's attention to the Prosecution Policy of the National Director of Public Prosecution (NDPP) which would effectively "grant immunity" to perpetrators who did not participate in and/or make a full disclosure to the Truth and Reconciliation Commission (TRC). It argued that this "obliterates the rights of victims of torture during the apartheid era to obtain redress" 63 and thus that this police was in contravention of the obligations that South Africa had undertaken in terms of article 14 of CAT. CSVR also noted that rehabilitation services for victims of torture are virtually non-existent. The AI submission raised similar concerns about prosecutions and emphasised that amnesties granted by the TRC left victims and families of victims without recourse to civil claims and criminal prosecutions. The submission further noted the tardiness of government in making a decision in respect of reparations paid to victims of gross human rights violation committed under apartheid and that the amount (R30 000.00) was substantially less than what was recommended by the TRC. ${ }^{64}$

\section{Article $16^{65}$}

Article 16 requires a State Party to prevent, in any territory under its jurisdiction, other acts of cruel, inhuman or degrading treatment or punishment which do not amount to torture but are committed at the instigation of or with the consent or acquiescence of a public official or other person acting in an official capacity. All six organisations made comments in respect of article 16 covering the following concerns: deaths in custody (police cells and prisons); use of

62 CAT (fn 19 above) article 14 states that:

"(1) Each State Party shall ensure in its legal system that the victim of an act of torture obtains redress and has an enforceable right to fair and adequate compensation, including the means for as full rehabilitation as possible. In the event of the death of the victim as a result of an act of torture, his dependants shall be entitled to compensation.

(2) Nothing in this article shall affect any right of the victim or other persons to compensation which may exist under national law."

63 Motala, Ernest, Bruce and Dissel (fn 55 above) 5.

64 Amnesty International (2006) (fn 54 above) 13-14.

65 CAT (fn 19 above) article 16

"(1) Each State Party shall undertake to prevent in any territory under its jurisdiction other acts of cruel, inhuman or degrading treatment or punishment which do not amount to torture as defined in article I, when such acts are committed by or at the instigation of or with the consent or acquiescence of a public official or other person acting in an official capacity. In particular, the obligations contained in articles 10,11,12 and 13 shall apply with the substitution for references to torture of references to other forms of cruel, inhuman or degrading treatment or punishment.

(2) The provisions of this Convention are without prejudice to the provisions of any other international instrument or national law which prohibits cruel, inhuman or degrading treatment or punishment or which relates to extradition or expulsion." 
excessive force by SAPS and DCS officials; prison overcrowding; the general conditions faced by prisoners; excessively long periods spent awaiting trial; rape in prisons; HIV/AIDS in prisons and access to anti-retroviral therapy; the use of violence by vigilante groups; trafficking of prisoners for sex; and long prison sentences. The submissions by the CRP and Global Initiative focused exclusively on corporal punishment of children and alleged that, although corporal punishment had been outlawed in South Africa, it was still taking place on a wide scale in state institutions and that perpetrators were seldom prosecuted. The submission by the World Organisation Against Torture provided a general overview of the violent nature of South African society and emphasised the vulnerability and large scale victimisation of women and children, with reference to rape and other sexual crimes.

\section{THE COMMITTEE'S RESPONSE: AN EVALUATION OF THE IMPACT OF CIVIL SOCIETY}

The Committee, in its Concluding Remarks, expressed its "profound satisfaction for the termination of the apartheid regime" and also welcomed South Africa's Initial Report. ${ }^{66}$ It noted that although the report was submitted late and did not fully comply with the Guidelines, the Committee was able to establish, through dialogue with the delegation, a clearer picture of measures taken to implement the provisions of the Convention. ${ }^{67}$ The Committee commended South Africa for a number of positive developments and noted, in particular, the peaceful transition to democracy, the adoption of a progressive Constitution (with specific reference to section 12 of that Constitution which deals with freedom and security of the person), the ratification of a wide range of international human rights instruments, and the adoption of progressive legislation and the establishment of institutions to promote and protect human rights. ${ }^{68}$ The Committee furthermore acknowledged the postapartheid challenges facing South Africa. ${ }^{69}$

In evaluating the influence of civil society on this process, it could plausibly be argued by the participating civil society organisations that their impact may be measured by looking at the congruence between the issues they raised with the Committee in their submissions and the issues of concern raised by the Committee in its Concluding Remarks. There is admittedly no proof that a concern identified by a civil society organisation was included in the Concluding Remarks because of the input by one of the civil society organisations, as the Committee might have included an issue of its own accord. In this regard it must be noted that the Committee does not reference or motivate why it is raising a particular concern. However, it is gratifying to note that, when comparing the issues raised by the civil society organisations in their submissions and the concerns raised by the Committee in the Concluding Remarks, there seems to be a great degree of congruence which

\footnotetext{
66 UN Committee against Torture (2006) (fn 22 above) paras 2 \& 3.

67 UN Committee against Torture (2006) (fn 22 above) par 3.

68 UN Committee against Torture (2006) (fn 22 above) paras 5-8.

69 UN Committee against Torture (2006) (fn 22 above) par 11.
} 
might at least provide anecdotal evidence that the civil society organisations made a real difference to the process.

In respect of articles 1, 4 and 15 the Committee lamented the absence of legislation criminalising torture and urged South Africa to adopt legislation implementing the absolute prohibition on torture, prohibiting the use of any statement obtained under torture and establishing that superior orders cannot be invoked as a justification of torture. ${ }^{70}$ In respect of article 3 the Committee emphasised the obligation of non-refoulement and requested the South African government to provide it with updated information on the status of Mohammed and Rashid. The Committee also expressed concern about the situation of non-citizens, their treatment and specifically the situation at the Lindela Repatriation Centre, ${ }^{71}$ and accordingly recommended thorough and independent investigations into complaints as well as the establishment of an effective monitoring mechanism..$^{72}$

The Committee raised a number of concerns relating to article 12. Mindful of the risk of immunity, and referring to crimes committed under apartheid, the Committee encouraged the South African government to bring to justice the persons responsible for the institutionalisation of torture as an instrument of oppression. The Committee expressed particular concern about those officials who did not apply for amnesty and/or did not make full disclosure to the TRC about their crimes. It linked this concern also to the wide discretionary powers given to the NDPP to decide on the prosecution of alleged perpetrators of human rights abuses, arguing that this in effect resulted in a de facto situation of immunity. Linked to crimes committed under apartheid, the Committee noted that not all victims of gross human rights violations had been compensated.

The high number of deaths in detention prompted the Committee to recommend the improvement of the investigative regime that would allow for perpetrators of torture to be brought to justice. The Committee also linked the wide discretionary powers of the NDPP to decide on which cases to prosecute to the weakness in current investigations. ${ }^{73}$

The Committee noted that complaints mechanisms in places of detention are not adequate and that this further weakened the ability to bring perpetrators of torture to justice. It therefore urged the South African government to improve legal aid mechanisms to ensure that victims of torture can exercise their rights under the Constitution and can seek redress. ${ }^{74}$

With reference to articles 11 and 16 , the Committee noted a number of

70 UN Committee against Torture (2006) (fn 22 above) paras $13 \& 14$.

71 The Lindela Repatriation Centre (Lindela) serves as a centralised detention facility for the apprehension of undocumented migrants awaiting determination of their legal status in South Africa and/or deportation. (South African Human Rights Commission (2000) Lindela at the Crossroads for Detention and Repatriation - an assessment of the conditions of detention by the South African Human Rights Commission, Johannesburg, 7 .

72 UN Committee against Torture (2006) (fn 22 above) par 16.

73 UN Committee against Torture (2006) (fn 22 above) par 18.

74 UN Committee against Torture (2006) (fn 22 above) par 20. 
concerns relating to detention conditions, overcrowding of facilities, human trafficking, lack of oversight and access to services. It urged the South African government to adopt effective measures, including legislation, to improve the situation. Also in relation to article 16, the Committee noted the high levels of violent crime perpetrated against women and children and recommended that the South African government "should adopt all necessary measures to prevent, combat and punish violence against women and children". ${ }^{75}$ It also urged the South African government to take effective measures to ensure that legislation banning corporal punishment in state institutions, such as schools and prisons, is indeed implemented and that this is monitored. ${ }^{76}$

Civil society organisations noted the general lack of public knowledge on CAT. The Committee acknowledged this and linked it to the fact that the South African government recognised the Committee's competence to receive individual communications under Article 22. However, no such communications had been received by the Committee since ratification. It therefore urged the South African government to widely disseminate CAT and information regarding CAT in all the appropriate languages. ${ }^{77}$ As a general comment, the Committee requested the State Party to

"provide in its next periodic report detailed disaggregated statistical data on complaints related to acts of torture, or cruel, inhuman or degrading treatment committed by law enforcement officials as well as of the investigations, prosecutions and convictions relating to such acts, including with regard to the abuses reportedly committed by South African peacekeepers. It further requests the State Party to provide detailed information on compensation and rehabilitation provided to the victims." 78

It also requested detailed information on the Bill criminalising torture as well as on progress made with regard to child justice legislation. The Committee further requested feedback within one year after issuing of its report ${ }^{79}$ on the following issues: the cases of Mohammed and Rashid; the situation of noncitizens and their treatment; efforts to strengthen legal aid; violence against women and children; statistical data on complaints and investigations into torture; and, importantly, the criminalisation of torture. ${ }^{80}$

It thus appears that there were in fact very few issues raised by civil society organisations that did not find their way into the Concluding Remarks. The six submissions by civil society representatives enabled the Committee to substantiate with more recent information a number of the issues raised in the Concluding Remarks. The Committee went further and prioritised a number of these, reflected in its request for feed-back within one year on selected concerns.

The Committee also raised a number of issues that were not explicitly noted

75 UN Committee against Torture (2006) (fn 22 above) par 23.

76 UN Committee against Torture (2006) (fn 22 above) par 25.

77 UN Committee against Torture (2006) (fn 22 above) par 26.

78 UN Committee against Torture (2006) (fn 22 above) par 27. During the Committee's interaction with the government delegation it became evident that some committee members were concerned about the behaviour of SANDF personnel as part of peacekeeping forces in Africa.

79 This deadline passed in November 2007.

80 UN Committee against Torture (2006) (fn 22 above) par 29. 
in the civil society organisations' submissions. The first concerns clarification on the State Party's jurisdiction over acts of torture in cases where an alleged offender is present in any territory under its jurisdiction. It furthermore requested information on progress made towards enacting child justice legislation, ${ }^{81}$ as well as any other legislation that may contribute towards the implementation of the Convention. It similarly requested information on training programmes for law enforcement officials as well as on monitoring mechanisms in mental health and other welfare institutions. The Committee also requested information on measures taken to prohibit the production, trade and use of equipment specifically designed to inflict torture or other cruel, inhuman and degrading treatment.

\section{CONCLUSION}

South Africa's Initial Report on CAT was the first opportunity for civil society organisations to participate in the work of the Committee against Torture and took on the form of several focused submissions reflecting in some measure the respective mandates of the organisations which had prepared them. An assessment of the content of these submissions and that of the Committee's Concluding Remarks indicates a high level of congruence between the concerns raised by the civil society organs and those highlighted by the Committee. This cannot conclusively be regarded as a cause-and-effect relationship and should rather be seen as the consolidation of shared concerns and the development of an inclusive South African agenda aimed at the prevention and combating of torture. The Concluding Remarks are, however, important because they will set the agenda for the follow-up procedure and the next Periodic Report. It must furthermore be assumed that issues emanating from the Concluding Remarks and the civil society organisation's submissions will find their way into the list of issues that will be distributed a year in advance of the consideration of the next period report. Given these implications and the time frames involved, it was indeed important for civil society to participate in the Committee's work, because this ensured that their concerns were placed on the monitoring agenda at an early stage and that they will remain there to be reviewed when the next Periodic Report is presented.

Despite the efforts from civil society organisations to participate in the Committee's work in Geneva, it appears that domestically the distance between government and civil society remains significant in respect of CAT. Following the $37^{\text {th }}$ Session of the Committee no formal dialogue has taken place between government and the civil society organisations regarding CAT, the feedback requested by the Committee by November 2007 or the preparation of the next Periodic Report which is due in December 2009. ${ }^{82}$ The draft bill aimed at criminalising torture also appears to have gone to ground. The reasons for government's lukewarm response to CAT are not clear, but seem to follow what

81 Child justice legislation was not raised by any of the civil society organisations in their original submissions, but was raised by the CRP in a supplementary submission following a question from a Committee member.

82 UN Committee against Torture (2006) (fn 22 above) par 31. 
is becoming an increasingly familiar pattern of ratifying international human rights treaties and then taking little action to give full effect to their objectives. ${ }^{83}$

The prevention and combating of torture have found political support from neither the ruling nor opposition parties, and even the national institutions for the promotion and protection and human rights have had a similarly distanced relationship with the issue. Given the widespread and systematic use of torture under apartheid, and its continued use after 1994, it appears that torture, 30 years after Steve Biko's death, leaves decision-makers cold. ${ }^{84}$ With the agenda set for the next four years, it appears that the efforts of civil society organisations should now be focussed domestically to promote CAT as well as the absolute prohibition and criminalisation of torture.

\section{BIBLIOGRAPHY}

A and others (FC) and others $v$. Secretary of State for the Home Department (2005) UKHL 71

Amnesty International (2006) South Africa - briefing for the committee against torture AFR 53/002/2006 London.

A (FC) and others (FC) $v$ Secretary of State for the Home Department (2004) UKHL 56

Bruce D Newham and Masuku T (2007) In Service of the People's Democracy - an assessment of the South African Police Service CSVR Johannesburg.

Department of Correctional Services (2007) Annual Report 2006/7 Pretoria.

Fernandez L and Muntingh L (forthcoming) The Criminalisation of Torture in South Africa, CSPRI Research Report.

Filartiga v Pena-Irala [1980] 630 F (2nd Series) 876 US Court of Appeals 2nd Circuit 890

Human Rights Commission (2000) Lindela at the Crossroads for Detention and Repatriation - an assessment of the conditions of detention by the South African Human Rights Commission Johannesburg.

Independent Complaints Directorate (2005) Annual Report 2004/5 Pretoria. Independent Complaints Directorate (2006) Annual Report 2005/6 Pretoria.

Mohammed and another $v$ President of the Republic of South Africa and Others 2001 (3) SA 893 (CC).

Prosecutor v Furundzija ICTY (Trial Chamber) No IT-95-17/1-T (10 December 1998)

Motala A, Ernest C, Bruce D and Dissel A (2006) Submission by the Centre

83 Similar lack of progress has also been noted in respect of reporting on the Convention on the Rights of the Child.

84 Following the death of Steve Biko on 12 September 1977, the then Minister of Justice and Police, Jimmy Kruger, addressed a National Party Congress on 14 September 1977 and expressed himself as follows: "I am not glad and I am not sorry about Mr. Biko. It leaves me cold (Dit laat my koud). I can say nothing to you. Any person who dies ... I shall also be sorry if I die. (Laughter)." (Bernstein H " No. 46 Steve Biko', http://www.sahistory.org.za/pages/library-resources/online\%20books/biko-no46/ iv-biko-death.htm) 
for the Study of Violence and Reconciliation to the UN Committee against Torture in response to "The Republic of South Africa - first Country report on the Implementation of the Convention against Torture, Cruel, Inhuman of Degrading Treatment or Punishment" Centre for the Study of Violence and Reconciliation Johannesburg.

Muntingh L and Fernandez L Civil Society Prison Reform Initiative (CSPRI) Submission to the UN Committee Against Torture In Response to "Republic Of South Africa - First Country Report On The Implementation Of The Convention Against Torture, And Other Cruel, Inhuman And Degrading Treatment Of Punishment", CSPRI, Bellville (2006).

Office of the Inspecting Judge (2006) Annual Report of the Judicial Inspectorate 2005/6 Cape Town.

Robertson G "Crimes against Humanity - the struggle for global justice", Penguin, London (2006).

Republic of South Africa (2002) "Initial Report to the Committee against Torture”, CAT/C/52/Add.3, 25 August 2005.

$R v$ Bow Street Metropolitan Stipendiary Magistrate, Ex p Pinochet Ugarte (No 3) (2000) 1 AC 147

Steve Biko Memorial Lecture delivered by the President of South Africa, Thabo Mbeki, on the occasion of the 30th Anniversary of the death of Stephen Bantu Biko Cape Town 12 September 2007 http://www.info.gov. $\mathrm{za} / \mathrm{speeches} / 2007 / 07091314151001$.htm Accessed on 25 September 2005.

UN Committee Against Torture (2002) Rules of Procedure, CAT/C/3/Rev.4, 9 August 2002.

UN Committee Against Torture (2004) "Summary record of the second part (public) of the 619th meeting”, 12 August 2004. CAT/C/SR.619/Add.1.

UN Committee against Torture (2005) Guidelines on the form and content of initial reports under Article 19 to be submitted by states parties to the Convention against Torture, CAT/C/4/Rev.3, 18 July 2005.

UN Committee against Torture (2006) "Consideration of Reports Submitted By States Parties Under Article 19 of the Convention Conclusions and recommendations of the Committee against Torture" - South Africa CAT/C/ZAF/ CO/1, 37th session, 6-24 November 2006.

UN Committee Against Torture, Working Methods http://www2.ohchr.org/ english/bodies/cat/workingmethods.htm\#a1 Accessed 9 May 2008.

UN Convention against Torture and Other Cruel, Inhuman or Degrading Treatment or Punishment, Adopted and opened for signature, ratification and accession by General Assembly resolution 39/46 of 10 December 1984, Entry into force 26 June 1987.

UN International Human Rights Instruments (2004) "Guidelines on an expanded core document and treaty-specific targeted reports and harmonized guidelines on reporting under the international human rights treaties", HRI/ MC/2004/3, 9 June 2004 http://www.unhchr.ch/tbs/doc.nsf/(Symbol)/HRI. MC.2004.3.En?Opendocument Accessed 9 May 2008. 